$\mathbf{R}_{\text {ESEARCH }} \mathbf{P}_{\text {APER }} \longrightarrow \frac{\text { FOOD SCIENCE }}{\text { RESEARCH JOURNAL }}$

\title{
Studies on the effect of stabilized rice bran supplementation on physico-chemical, microbial and textural quality of bread
}

\author{
J.K. SAngle, A.R. Sawate, B.M. Patil and R.B. Kshirsagar
}

This project was designed to evaluate the suitability of stabilized rice bran for the supplementation of bread. Freshly milled rice bran was treated with autoclave heating for its stabilization. The effect of stabilized rice bran supplementation on physico-chemical, microbial and textural quality of wheat bread was determined. Blends of wheat flour and rice bran (95:5, 90:10, 85:15 and 80:20) were used to bake bread with 100 per cent wheat flour as control. The physical properties of bread were evaluated and found that loaf weight increased with increasing per cent of rice bran flour into refined wheat flour. The loaf volumes of bread made from composite flour were lower than those made from control wheat flour. The effect of different levels of stabilized rice bran on crust and crumb colour of bread was evaluated. Results showed that lightness of crust and crumb of wheat bread gets decreased with increased level of stabilized rice bran. Also, redness (a) and yellowness (b) increased with increased level of stabilized rice bran. The proximate composition of the bread samples was analyzed. The moisture, crude protein, crude fat, crude fibre and ash contents increased significantly from 31.12 per cent to 33.98 per cent, 11.87 per cent to 13.38 per cent, 1.52 per cent to 3.95 per cent, 0.82 per cent to 2.65 per cent and 1.52 per cent to 2.09 per cent, respectively; with increased level of supplementation. The carbohydrate contents decreased with increased level of supplementation from 53.13 per cent to 43.92 per cent. The microbial properties shown that there was no significant difference in total plate count and yeast and mould count of functional wheat bread on increasing the supplementation of rice bran flour. The texture profile analysis showed that hardness and chewiness of functional wheat bread was increased with increase in supplementation of rice bran flour. There was no significant difference in springiness and cohesiveness of wheat bread supplemented with stabilized rice bran.

Key Words : Composite Bread, Rice bran, Supplementation, Microbial quality, Textural quality.

How to cite this article : Sangle, J.K., Sawate, A.R., Patil, B.M. and Kshirsagar, R.B. (2017). Studies on the effect of stabilized rice bran supplementation on physico-chemical, microbial and textural quality of bread. Food Sci. Res. J., 8(1): 35-42, DOI : 10.15740/ HAS/FSRJ/8.1/35-42.

\section{MEMBERS OF RESEARCH FORUM}

Author for correspondence :

J.K. SANGLE, Department of Food Engineering, College of Food Technology,

Vasantrao Naik Marathwada Krishi Vidyapeeth, PARBHANI (M.S.) INDIA

Associate Authors' :

A.R. SAWATE, B.M. PATIL AND R.B. KSHIRSAGAR, Department of Food

Engineering, College of Food Technology, Vasantrao Naik Marathwada Krishi

Vidyapeeth, PARBHANI (M.S.) INDIA 